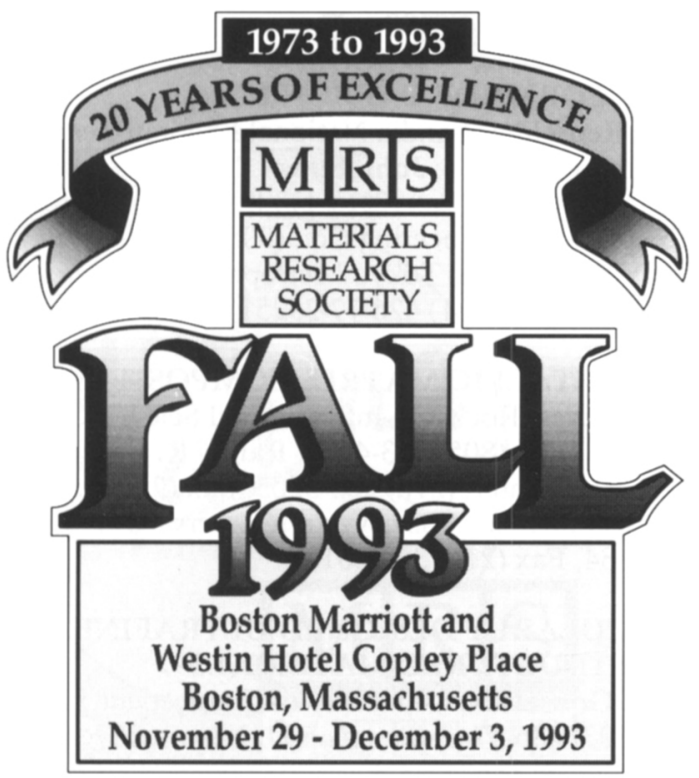

\section{TECHNICAL PROGRAM}

AA:Atomic Scale Imperfections in Materials - R.W. Balluffi Fest

A: Materials Synthesis and Processing Using Ion Beams

B: Mechanisms of Thin Film Evolution

Ca: Interface Control of Electrical, Chemical, and Mechanical Properties

$\mathrm{Cb}$ : Defect-Interface Interactions

D: Silicides, Germanides, and Their Interfaces

E: Crystallization and Related Phenomena in Amorphous Materials - Ceramics, Metals, Polymers, and Semiconductors

F: High-Temperature Silicides and Refractory Alloys

G: Fullerenes and Related Materials

H: Superconductivity - Materials and Properties

I: Developing Materials Processes for Factories

J: Electronic Packaging Materials Science VII

K: Diagnostic Techniques for Semiconductor Materials Processing

L: Defects in Advanced Semiconductors - Physics and Applications

M: Growth, Processing and Characterization of Semiconductor Heterostructures

$\mathrm{N}$ : Covalent Ceramics II: Non-Oxides

0: Complex Fluids

P: Disordered Materials - Fractals, Scaling, and Dynamics

Q: Electrical, Optical, and Magnetic Properties of Organic Solid State Materials

R: New Materials for Advanced Solid State Lasers

S: Biomolecular Materials by Design

T: Biomaterials for Drug and Cell Delivery

U: Determining Nanoscale Physical Properties of Materials by Microscopy and Spectroscopy

V: Scientific Basis for Nuclear Waste Management XVII

W: Gas-Phase and Surface Chemistry in Electronic Materials Processing

$\mathrm{X}$ : Frontiers of Materials Research

Y: Metal-Organic Chemical Vapor Deposition of Electronic Ceramics
- New Materials Development

- New Characterization Methods

- New Process Technology

The 1993 Fall Program and Registration Materials book will be available in mid-September. If you would like a copy mailed to you, fax your request to: MRS 1993 Fall Program, (412) 367-4373.

\section{SHORT COURSE PROGRAM}

Courses on advanced materials characterization, preparation, and processing/diagnostic techniques have been designed for scientists, engineers, managers, and technical staff who wish to update their knowledge and skills in the research, development and processing of materials. These up-to-date courses are at the forefront of science and technology and complement Fall Meeting symposia. Class sizes are limited. Early preregistration is encouraged.

\section{EQUIPMENT EXHIBIT AND TABLE-TOP DISPLAY}

A major exhibit and table-top display of the latest analytical and processing equipment which closely parallels the nature of the technical symposia will be located in the Boston Marriott Hotel, convenient to the technical session rooms. For information, contact Merry Geil, Director of Meeting Activities, Materials Research Society, 9800 McKnight Road, Pittsburgh, PA 15237 • Telephone (412) 367-3003; Fax (412) 367-4373.

\section{PROCEEDINGS}

Many symposia from this meeting will publish proceedings. MRS members and meeting attendees may purchase copies of these proceedings at special prepublication prices and receive priority shipment upon publication. Prices will be higher following the meeting. To take advantage of these special prices, order your proceedings while registering for the meeting. For information on nonmember proceedings prices and ordering procedures, contact the MRS Publications Department.

\section{SYMPOSIUM AIDE OPPORTUNITIES}

By applying for Symposium Aide positions, graduate students who plan to attend the MRS 1993 Fall Meeting and are willing to assist in the symposium presentations can earn a waiver of the student registration fee, a one-year MRS student membership beginning January 1, 1994, and a stipend to help cover expenses.

\section{JOB PLACEMENT CENTER}

A Job Placement Center for MRS meeting and short course attendees will be open Tuesday through Thursday during the meeting adjacent to the Equipment Exhibit.

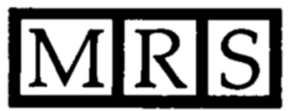

Materials Research Society

9800 McKnight Road, Pittsburgh, PA 15237-6006

Telephone (412) 367-3003 • Fax (412) 367-4373

The 1993 MRS Fall Meeting will serve as a key forum for discussion of interdisciplinary leading-edge materials research from around the world. Various meeting formats - oral, poster, roundtable, forum and workshop sessions - are offered to maximize participation. 


\section{PREREGISTRATION 1993 MRIS FALL MEETING}

\begin{tabular}{|lccc} 
MAIL Return this form with payment to: & PHONE Call the MRS Meeting Registration Desk, & FAX Transmit this order form via Fax to \\
Materials Research Society & $\begin{array}{l}\text { (412) } 367-3003, \text { between 8:00 a.m. and 5:00 p.m. } \\
\text { Meeting Registration }\end{array}$ & Eastern time. Telephone registration requires & $(412) 367-4373$, in service 24 hours \\
9800 McKnight Road & credit card payment; have your credit card and & a day. Fax registration requires \\
Pittsburgh, PA 15237-6006 & this form in front of you for easy reference. & credit card payment.
\end{tabular}

\section{PREREGISTRATION DEADLINE: NOVEMBER 19, 1993}

NOTE: Please enter MRS code from mailing

label $(0 . .$.$) . If this is not your own copy, enter$

the code from the label and check here. $\square$

If you do not have a mailing label code, draw a

line through code box at right.

Please fill in form completely and legibly to assure proper processing. This address is: $\square$ Business $\square$ Home $\square$ Address Change

Name

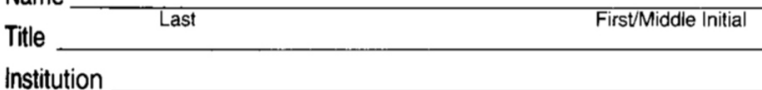

Department

Street Address

P.O. Box

City

State/Province

Zip/Postal Code

Country

Telephone $\left(\frac{}{\text { Area Code }}\right)$

E-Mail Address

MRS

E-Mail Network: $\square$ Internet $\quad \square$ Bitnet $\quad \square$ Other

MRS selectivity permits use of its membership list by advertisers of products which the Society deems to be of high interest to MRS members. Please check if you do not wish to receive these mailings.

\section{A. MEETING PREREGISTRATION}

Please check category and enter amount in payment section below.

- \$260 Member/Nonmember through November 19, 1993;

$\$ 310$ after November 19, 1993

$\square \$ 70$ Student Member/Nonmember* through November 19, 1993;

$\$ 80$ after November 19, 1993

"Student must provide proof of full-time student status at time of submission

of registration (class schedule with student's name or signed letter from the taculty advisor or registrar).

$\square \$ 100$ Short Course attendee registered for at least two full course days

Meeting registration includes complimentary one-year MRS membership beginning January 1, 1994.

\section{Symposium interest (please check all that apply):}
$\square \mathrm{AA} \square \mathrm{B} \square \mathrm{Cb} \square \mathrm{E} \square \mathrm{G} \square \mathrm{I} \square \mathrm{K} \square \mathrm{M} \square$
$\square \mathrm{A} \square \mathrm{Ca} \square \mathrm{D} \square \mathrm{F} \square \mathrm{H} \sqsupset \mathrm{L} \square \mathrm{N} \square \mathrm{P}$ Enter total here and in box below right.
$\square \mathrm{Q} \square \mathrm{S} \square \mathrm{U} \square \mathrm{W}$
$R \square T \square V \square Y$
TOTAL \$

If you have already registered and paid and find that you are unable to attend, you must notify MRS IN WRITING of your request for a refund. Refunds will be made upon receipt of written notice, less a \$25 service charge. This service charge will be waived if you apply $\$ 25$ or more of this refund to any other MRS product or service. MRS will not honor requests made more than one calendar month after the close of the meeting.

\section{PROCEEDINGS} Con only to meeting and short course attendees, and MRS members. Nonmembers must contact MRS headquarters for prices.

\begin{tabular}{|c|c|c|}
\hline \multirow[b]{2}{*}{ A } & \multicolumn{2}{|c|}{ No. Copies } \\
\hline & Ion Beam Synthesis \& Processing ......... & $\mathrm{x}$ \\
\hline B: & Thin Film Evolution & $\mathrm{x}$ \\
\hline $\mathrm{Ca}$ & : Interface Control of Properties & $\mathrm{x}$ \\
\hline $\mathrm{Cb}$ & Defect-Interface Interactions & $\mathrm{x}$ \\
\hline D: & Silicides, Germanides \& Interfaces & $\mathrm{x}$ \\
\hline $\mathrm{E}:$ & Amorphous Material Crystallization & $\mathrm{x}$ \\
\hline $\mathrm{F}$ : & High-Temp. Silicides/Refractory Alloys ... & $\mathrm{x}$ \\
\hline J: & Electronic Packaging & $\mathrm{x}$ \\
\hline $\mathrm{K}$ : & Semiconductor Materials Processing . & $\mathrm{x}$ \\
\hline $\mathrm{L}:$ & Defects in Semiconductors & $\mathrm{x}$ \\
\hline M: & Semiconductor Heterostructures ... & $x$ \\
\hline $\mathrm{N}:$ & Covalent Ceramics (Non-Oxides) & $x$ \\
\hline Q: & Organic Solid State Materials ........ & $x$ \\
\hline R: & Materials for Solid State Lasers ...... & $x$ \\
\hline S: & Biomolecular Materials by Design ..................... & $x$ \\
\hline & Biomaterials for Drug \& Cell Delivery ........... & $x$ \\
\hline U: & Nanoscale Properties ......................... & $x$ \\
\hline V: & Nuclear Waste Management & $x$ \\
\hline W & Gas-Phase/Surface Chem. in Elec. Mats. ... & $x$ \\
\hline & MOCVD of Electronic Ceramics & \\
\hline
\end{tabular}

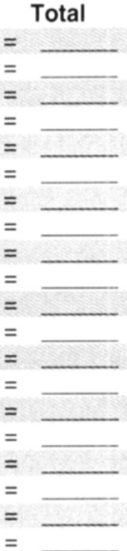

Sub-Total

$6 \%$ Sales Tax (PA residents only)

TOTAL

\section{JOURNAL OF MATERIALS} RESEARCH 1994

Subscription at Member Rate (one per registrant)...... $\square 50=$ TOTAL $\$$ Enter total here and in box below.

To preregister, check each short course/tutorial in which you wish to enroll. If you register for two or more short course days, you may attend the technical meeting for only \$100; just complete the Meeting Preregistration section at left.

At-meeting short course and tutorial registrations will be $\$ 25$ higher. Cancellations received by November 19,1993, will be refunded less a service charge of $\$ 25$. There is no charge for transferring from one short course to another or from one tutorial to another.

\section{ID SHORT COURSES}

Facilities registering three or more persons at the same time in one MRS Short Course receive a $20 \%$ discount for the third and all additional persons.

$\square$ C-01 Modern Materials Analysis Techniques.

C-03 Surface and Thin Film Analysis

C-14 STM and AFM

C-20 Optical Characterization of III-V SC Epitaxial Layers

C-23 X-Ray Diffraction Characterization of Semiconductor Wafers

C-29 Practical Electron Diffraction

C-30 Characterization and Properties of Inorganic Thin Films

C-31 Near-Field Scanning Optical Microscopy

F-02 Plasma Etching

F-10 Ion Beam Assisted Deposition

P-02 Molecular Beam Epitaxy

P-04 Film Formation, Adhesion, and Surface Preparation

P-10 MOCVD and ALE

P-25 CVD for Metallization Applications

P-26 Metallization for Devices, Circuits \& Packaging/VLSI \& ULSI ...

M-15 Biological Processes for Materials Synthesis

$\mathrm{M}-16$ Ferroelectric Thin Films.

M-19 Wide Bandgap II-VI SC Microstructures

T-05 Plasma Technology for Thin Film Deposition........

\section{Combined Tuition Fees}

Any combination of T-05, P-04, F-02, C-30, and F-10 that results in 2, 3, 4, and 5 course days: $\$ 595, \$ 795, \$ 995$, and 1,195 , respectively. Any combination of C-23, P-10, P-02, and C-20 that results in 2, 3 , and 4 course days: $\$ 595, \$ 795$, and $\$ 995$, respectively.

\section{ב TUTORIALS}

TP-1 Transfer of Technology from R\&D to Manufacturing ......................\$115

TP-2 Fractals in Materials Science ........................................... \$75

TP-3 Fullerenes

TP-5 Light-Emitting Porous Silicon

TP-6 Design \& Processing of Materials by Biomimetics

TOTAL SHORT COURSETUTORIAL TUITION \$

Enter total here and in box below.

\section{PAYMENT OPTIONS}

Payment is enclosed. Make checks payable, in U.S. dollars, to

Materials Research Society. Payment from outside the U.S. should be drawn on a correspondent U.S. bank.

Credit card payment: $\square$ Visa $\square$ MasterCard $\square$ Diners Club $\square$ AmEx Card number Exp. date

Signature
Registrations received without paym
Meeting Preregistration (from left)
B Proceedings (from left)
C Journal of Materials Research (from above)
D/E Short Courses/Tutorials (from above)

TOTAL FEES PAID \$

- If you are unemployed or retired and are a current or former member of MRS, or a recent graduate not yet employed, reduced registration rates are available. To learn if you are eligible, contact the MRS Meetings Department via mail, phone, or fax (numbers are listed at the top of this form).

The Materials Research Society wishes to comply with the Americans with Disabilities Act by taking those steps necessary to ensure that no individual with a disability is excluded from participation in MRS meetings. If you have a disability requiring accommodation at the 1993 Fall Meeting, please attach a written description of your needs.
For Accounting Use Only

Check \#

Date

Batch \#

Total

Type 


\section{GENERAL MEETING INFORMATION}

\section{Location/Lodging}

\section{Boston Marriott/ Copley Place}

110 Huntington Avenue

Boston, MA 02116

(800) 228-9290

(617) 236-5800 (Direct)

Fax (617) 236-5885

Rate: $\$ 114 /$ Single

$\$ 128$ Double

\author{
Westin Hotel/ \\ Copley Place \\ 10 Huntington Avenue \\ Boston, MA 02116 \\ (800) 228-3000 \\ (617) 262-9600 (Direct) \\ Fax (617) 424-7483 \\ Rate: $\$ 118 /$ Single \\ \$143 Double
}

DEADLINE FOR HOTEL RESERVATIONS: NOVEMBER 1, 1993

Blocks of rooms have been reserved for MRS meeting attendees at the Boston Marriott and Westin Hotels (above) and at the alternative hotels (below) located within a one-block radius. When making your reservations at any hotel, mention the Materials Research Society to receive the special rates.

\section{- Alternative Housing}

\section{The Colonnade}

Phone: (617) 424-7000

Fax: $\quad$ (617) 424-1717

Rate: $\$ 130 /$ Single-Double

Sheraton Boston Hotel \& Towers

Phone: (617) 236-2000

Fax: (617) 236-1702

Rate: \$109/Single

\$119/Double
The Lenox Hotel

Phone: (617) 536-5300

Fax: (617) 266-7905

Rate: \$100/Single \$110/Double

\section{Travel Arrangements}

The official travel management company for the Materials Research Society's 1993 Fall Meeting is Giselle's Travel Bureau. They will guarantee the lowest fares on any airline at time of booking. Call Giselle's and ask for MRS Group 001 1-800-782-5545

Monday - Friday, 7:30 a.m. - 5:30 p.m. PST

FAX: (916) 927-0454 or 1-800-TRVLFAX

MRS meeting attendees receive the following travel benefits and services:

Lowest fares on any airline guaranteed - Free flight insurance of $\$ 100,000$ - Vouchers for discounts on vacation packages $\cdot$ Car rental savings - Computerized driving instructions from Logan International Airport to your hotel

ONE MRS MEETING ATTENDEE WILL WIN TWO (2) FREE AIRLINE TICKETS TO ANYWHERE IN THE 48 UNITED STATES.

To be eligible: You, your travel agent, or your in-house trave department must make your reservations through Giselle's Travel Bureau by calling the above phone number.

- Local Transportation

Shuttle service to the Boston Marriott and Westin Hotels from Logan International Airport departs every half-hour from the designated shuttle stop in front of each terminal. The cost is approximately $\$ 6-\$ 8$ one way. Cab fares range between $\$ 15-\$ 17$ per ride (up to four persons can share one cab).

There is a free shuttle from airport terminals to the airport subway station (The "T"). Copley Station is within one block of the Marriott, Westin, and alternative hotels on the "Green Line."

- Parking

A parking garage is adjacent to both hotels at a daily cost of approximately $\$ 21$

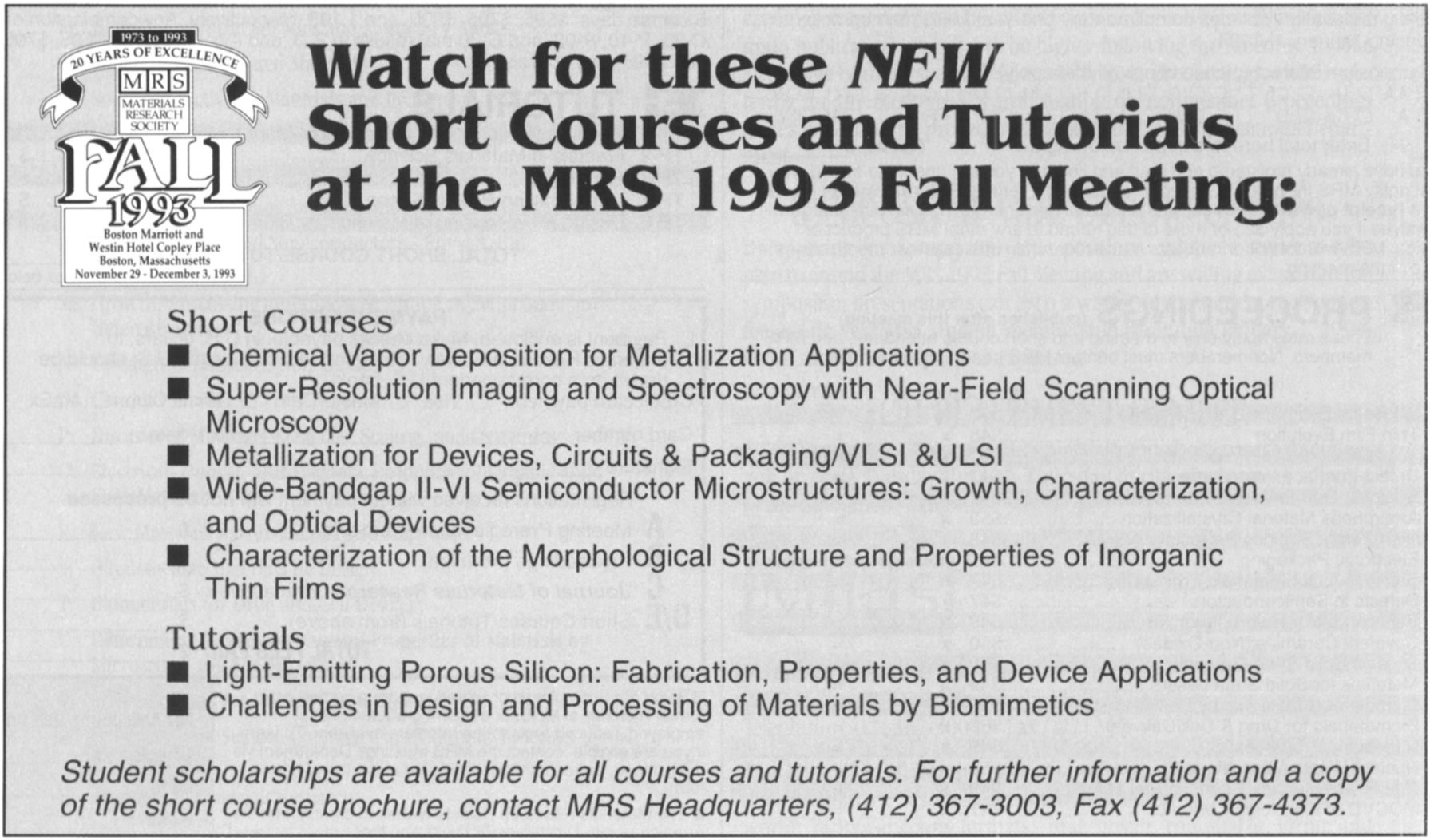

